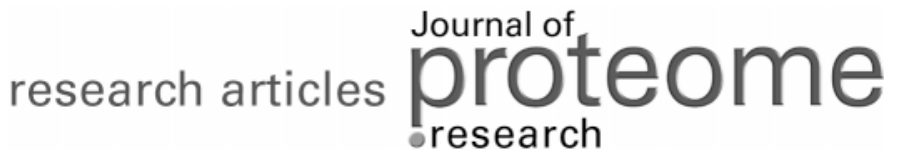

\section{A Method for the Rapid and Efficient Elution of Native Affinity-Purified Protein A Tagged Complexes}

\author{
Caterina Strambio-de-Castillia, ${ }^{\dagger}$ Jaclyn Tetenbaum-Novatt, ${ }^{\dagger}$ Brian S. Imai, ${ }^{\ddagger}$ Brian T. Chait, ${ }^{\S}$ and \\ Michael P. Rout ${ }^{*, \dagger}$
}

The Rockefeller University, 1230 York Avenue, New York New York 10021-6399

Received May 24, 2005

\begin{abstract}
A problem faced in proteomics studies is the recovery of tagged protein complexes in their native and active form. Here we describe a peptide, Bio-Ox, that mimics the immunoglobulin G (IgG) binding interface of Staphylococcus aureus Protein A, and competitively displaces affinity-purified Protein A fusion proteins and protein complexes from IgG-Sepharose. We show that Bio-Ox elution is a robust method for the efficient and rapid recovery of native tagged proteins, and can be applied to a variety of structural genomics and proteomics studies.
\end{abstract}

Keywords: Staphylococcus aureus $\bullet$ Protein A • affinity purification • proteomics $\bullet$ fusion protein

\section{Introduction}

Protein-protein interactions are central to the maintenance and control of cellular processes. The study of such proteinprotein interactions has been greatly enhanced by fusion protein technology, wherein specific peptide or protein domain "tags" are fused to the protein of interest (generally at either its carboxyl-terminus or amino-terminus). These tags can facilitate the detection, increase the yield, and enhance the solubility of their associated proteins. ${ }^{1-3}$ Most importantly, these fusion domains have been exploited to allow the singlestep purification of the test protein either alone or in complexes with its in vivo binding partners. ${ }^{4-6}$ The yield of these purification methods is often high enough to allow the identification of such binding partners by mass spectrometry.

A commonly used affinity tagging method generates genomically expressed Protein A (PrA) fusion proteins by modifying the coding sequence of the protein under study via PCRdirected approaches. ${ }^{7-9}$ This method takes advantage of the $\sim 10 \mathrm{nM}$ binding affinity of PrA from Staphylococcus aureus for the constant region (Fc) of immunoglobulin G (IgG). ${ }^{10}$ After purification on IgG-conjugated resins, PrA-tagged proteins or protein complexes are most commonly eluted from the resin using high or low $\mathrm{pH}$ conditions. These elution methods typically lead to the denaturation of the isolated proteins, the dissociation of complexes, and concomitant loss of activity. However, it is often desirable to recover soluble native protein or protein complexes. One method by which this can be achieved is by constructing a cleavable tag. Such tags carry a specific cleavage site for a protease placed proximal to the tagged protein, allowing the tag to be removed from the fusion protein. Proteases that are widely used for this purpose include

\footnotetext{
* To whom correspondence should be addressed. Tel: +1 (212) 327-8135 E-mail: rout@mail.rockefeller.edu.

${ }^{\dagger}$ Laboratory of Cellular and Structural Biology, Box 213.

‡ Proteomics Resource Center, Box 105.

${ }^{\S}$ Laboratory of Mass Spectrometry and Gaseous Ion Chemistry, Box 170.
}

10.1021/pr0501517 CCC: $\$ 30.25$ C xxxx American Chemical Society blood coagulation factors X (factor Xa), enteropeptidase (enterokinase), alpha-thrombin, and the tobacco etch virus (TEV) protease. Nevertheless, this method has drawbacks. First, the literature is replete with reports of fusion proteins that were cleaved by these proteases at sites other than the canonical cleaving site. ${ }^{11-14}$ Second, the removal of the tag destroys the ability to detect or further purify the protein of interest, necessitating the encumbrance of a second, tandem tag. ${ }^{15}$

Here, we describe a rapid single step method for the efficient recovery of native and active PrA fusion proteins and protein complexes from IgG-Sepharose. This technique avoids the complications of having to use a protease and in addition has the advantage of retaining the original tag on the target protein after elution, permitting further purification steps and detection of the fusion protein in subsequent experiments. Our method takes advantage of a previously described peptide, termed FcIII, ${ }^{16}$ which mimics the protein-protein binding interface of PrA for the hinge region on the Fc domain of human IgG. We modified FcIII by the addition of a biotin moiety to its aminoterminus to increase the peptide's solubility while leaving its affinity for Fc intact - making it a more effective elution reagent. We termed this modified peptide, Bio-Ox.

To investigate the properties of Bio-Ox, PrA-tagged proteins were isolated in their native state from yeast on an IgGconjugated Sepharose resin, either alone or in combination with their in vivo interacting partners; the Bio-Ox peptide was then used to competitively displace the tagged proteins and elute them from the resin. The efficiency of elution was monitored by quantitatively comparing the amounts of proteins eluted to the amounts remaining on the resin under a variety of test conditions. We show that Bio-Ox elution is a robust method for the efficient and rapid recovery of native tagged proteins that can be applied to a variety of structural genomics and proteomics studies. 


\section{Experimental Section}

Peptide Synthesis, Oxidation and Cyclization. Peptides were synthesized using standard Fmoc protocols. Typical deprotection times with $20 \%$ piperidine were 2 times 10 min and typical coupling times with 4-10-fold excess of amino acids over resin were 2 to $6 \mathrm{~h}$. Small batches of peptides were made on a Symphony synthesizer (Protein Technologies, Inc.), while larger batches were made manually. Peptides were cleaved from the resin using $94.5 \%$ trifluoroacetic acid, $2.5 \%$ water, $2.5 \%$ ethanedithiol and $1 \%$ triisopropylsilane for $3 \mathrm{~h}$ at $25{ }^{\circ} \mathrm{C}$. The solubilized peptides were precipitated with 10 volumes of cold tert-butyl methyl ether and the precipitated peptide was washed several times with ether prior to air-drying. The airdried peptide was dissolved in $20 \%$ acetonitrile in water to approximately $0.5 \mathrm{mg} / \mathrm{mL}$, the $\mathrm{pH}$ was adjusted to 8.5 using sodium bicarbonate and the peptide was allowed to air oxidize overnight to promote cyclization. The progress of cyclization was monitored by mass spectrometry. The cyclized crude peptide was purified using standard preparative reversed phase HPLC using a Vydac 218TP1022 C18 column.

Peptide Solubility. Eluting peptides were suspended at a concentration of $440 \mu \mathrm{M}(0.77 \mathrm{mg} / \mathrm{mL}$ for BioOx; $0.67 \mathrm{mg} / \mathrm{mL}$ for FcIII), in peptide buffer by extensive vortexing. The peptide concentration was verified by measuring the $\mathrm{OD}_{280 \mathrm{~nm}}$ of each solution (extinction coefficient: $1 \mathrm{OD}_{280 \mathrm{~nm}}=0.13 \mathrm{mg} / \mathrm{mL}$ ). The peptide solutions/suspensions were then combined with equal amounts of a $100 \mathrm{mM}$ buffer to obtain $\sim 220 \mu \mathrm{M}$ peptide at a range of $\mathrm{pH}$ values (buffers: Na-Acetate $\mathrm{pH} 4.8$, Na-Citrate $\mathrm{pH}$ 5.4, Na-Succinate $\mathrm{pH}$ 5.8, Na-MES pH 6.2, BisTris-Cl pH 6.5, Na-HEPES pH 7.4, Na-TES pH 7.5, Tris-Cl pH 8.3, Na-CAPSO $\mathrm{pH}$ 9.6). Samples were incubated at room temperature with gentle agitation for $20 \mathrm{~min}$, and then insoluble material was removed by centrifugation at $21000 \times g_{\max }$ for $20 \mathrm{~min}$ at 25 ${ }^{\circ} \mathrm{C}$. The concentration of peptide in each remaining supernatant was determined by measuring its $\mathrm{OD}_{280} \mathrm{~nm}$.

To determine the maximum solubility of each peptide, the peptides were dissolved to saturation in peptide buffer by extensive vortexing and incubation with stirring at $25{ }^{\circ} \mathrm{C}$ overnight. Insoluble material was removed by centrifugation at $15000 \times g$ for $15 \mathrm{~min}$ at $25^{\circ} \mathrm{C}$ and the amount of dissolved peptide was measured directly by amino acid analysis.

Peptide Competitive Displacement of Bound Recombinant PrA from IgG-Sepharose. Recombinant PrA (280 $\mu \mathrm{g} ; 6.7 \mathrm{nmol})$ from S. aureus (Pierce) was dissolved in $1 \mathrm{~mL}$ TB-T $[20 \mathrm{mM}$ HEPES-KOH pH 7.4, 110 mM KOAc, $2 \mathrm{mM} \mathrm{MgCl}_{2}$, 0.1\% Tween20 (vol/vol)] and added to $280 \mu \mathrm{L}$ of packed pre-equilibrated Sepharose 4B (Amersham Biosciences) conjugated with affinitypurified rabbit IgG (ICN/Cappel; 1.87 nmoles IgG). After incubation on a rotating wheel overnight at $4{ }^{\circ} \mathrm{C}$, the resin was washed twice with $1 \mathrm{~mL}$ TB-T, twice with $1 \mathrm{~mL}$ TB-T containing $200 \mathrm{mM} \mathrm{MgCl}_{2}$, and twice with $1 \mathrm{~mL}$ TB-T. After the final wash, the resin was divided evenly into 14 equal aliquots. The peptide was dissolved in peptide buffer at concentrations ranging between 0 and $440 \mu \mathrm{M}$ peptide. Aliquots of $400 \mu \mathrm{L}$ of the appropriate peptide solution was added to each PrA-IgGSepharose containing tube, and the tubes were then incubated on a rotating platform for $3 \mathrm{~h}$ at $4{ }^{\circ} \mathrm{C}$ followed by $1 \mathrm{~h}$ at $25^{\circ} \mathrm{C}$. After displacement of bound PrA from the IgG-Sepharose, the resin was recovered by centrifugation on a Bio-Spin column (BioRad), and resuspended in one-bed volume of sample buffer. Samples were separated by SDS-PAGE.

Yeast Strains. Strains are isogenic to DH5alpha unless otherwise specified. All yeast strains were constructed using standard genetic techniques. C-terminal genomically tagged strains were generated using the PCR method previously described..$^{7,17}$

Affinity Purification of Proteins and Protein Complexes on IgG-Sepharose. The protocol for the purification of PrAcontaining complexes was modified from published methods. ${ }^{18-20}$ For the purification of Kap95p-PrA, yeast cytosol was prepared essentially as previously described. ${ }^{21,22}$ Kap95pPrA cytosol was diluted with 3.75 volumes of extraction buffer 1 [EB1: 20 mM Hepes/KOH, pH 7.4, 0.1\% (vol/vol) Tween-20, $1 \mathrm{mM}$ EDTA, $1 \mathrm{mM}$ DTT, $4 \mu \mathrm{g} / \mathrm{mL}$ pepstatin, $0.2 \mathrm{mg} / \mathrm{mL}$ PMSF]. The diluted cytosol was cleared by centrifugation at $2000 \times g_{\mathrm{av}}$ for $10 \mathrm{~min}$ in a Sorvall T6000D tabletop centrifuge and at $181000 \times g_{\max }$ for $1 \mathrm{~h}$ in a Type $80 \mathrm{Ti}$ Beckman rotor at $4{ }^{\circ} \mathrm{C} .10$ $\mu \mathrm{L}$ bed volume of IgG-Sepharose pre-equilibrated in EB1 was added per $0.5 \mathrm{~mL}$ of cytosol and the binding reaction was incubated overnight at $4{ }^{\circ} \mathrm{C}$ on a rotating wheel. The resin was recovered by centrifugation at $2000 \times g_{\text {av }}$ for $1 \mathrm{~min}$ in a Sorvall T6000D tabletop centrifuge, transferred to $1.5 \mathrm{~mL}$ snap-cap tubes (Eppendorf), and washed 6 times with EB1 without DTT. For the purification of Nup82p-PrA, cells were grown in Whickerham's medium ${ }^{21}$ to a concentration of $4 \times 10^{7}$ cells/ $\mathrm{mL}$, washed with water and with $20 \mathrm{mM}$ Hepes/KOH $\mathrm{pH}$ 7.4, $1.2 \% \mathrm{PVP}$ (weight/vol), $4 \mu \mathrm{g} / \mathrm{mL}$ pepstatin, $0.2 \mathrm{mg} / \mathrm{mL}$ PMSF, and frozen in liquid $\mathrm{N}_{2}$ before being ground with a motorized grinder (Retsch). Ground cell powder $(1 \mathrm{~g})$ was thawed into 10 $\mathrm{mL}$ of extraction buffer 2 [EB2; 20mM Na-HEPES, $\mathrm{pH} 7.4,0.5 \%$ TritonX-100 (vol/vol), 75mM NaCl, $1 \mathrm{mM} \mathrm{DTT,} 4 \mu \mathrm{g} / \mathrm{mL}$ pepstatin, $0.2 \mathrm{mg} / \mathrm{mL} \mathrm{PMSF}$. Cell lysates were homogenized by extensive vortexing at $25^{\circ} \mathrm{C}$ followed by the use of a Polytron for $25 \mathrm{~s}$ (PT 10/35; Brinkman Instruments) at $4{ }^{\circ} \mathrm{C}$. Clearing of the homogenate, binding to IgG-Sepharose, resin recovery and washing was done as above except that $10 \mu \mathrm{L}$ of IgG-Sepharose bed volume was used per $1 \mathrm{~g}$ of cell powder and EB2 without DTT was used for all the washes. Elution of the PrA tagged complexes was performed as described below.

Peptide Elution of Test Proteins and Protein Complexes and Removal of Peptide by Size Exclusion. Kap95p-PrA or Nup82p-PrA bound IgG-Sepharose resin was recovered over a pre-equilibrated Bio-Spin column (BioRad) by centrifugation for $1 \mathrm{~min}$ at $1000 \times g_{\max }$. Three bed-volumes of $440 \mu \mathrm{M}$ (unless otherwise indicated in the text) of eluting peptide in peptide buffer were added per volume of packed IgG Sepharose resin. The elution was carried out for various times (as indicated in the text) at either $4{ }^{\circ} \mathrm{C}$ or at $25^{\circ} \mathrm{C}$. When elution was complete, the eluate was recovered over a Bio-Spin column. Finally, the resin was washed with one bed-volume of elution buffer to displace more eluted material from the resin and the wash was pooled with the initial eluate. The peptide was removed by filtration of the eluate over a micro spin G25 column (Amersham Biosciences) as described by the manufacturer.

Kap95p-Nup2p in Vitro Binding Experiments. To demonstrate in vitro binding of proteins after elution from the resin, Kap95p-PrA from $0.3 \mathrm{~mL}$ of yeast cytosol was affinity-purified on $17.5 \mu \mathrm{L}$ of packed IgG-Sepharose and eluted with $52.5 \mu \mathrm{L}$ of $440 \mu \mathrm{M}$ Bio-Ox for $2.5 \mathrm{~h}$ at $4{ }^{\circ} \mathrm{C}$ followed by $1 \mathrm{~h}$ at $25^{\circ} \mathrm{C}$. The resulting sample (total volume $88 \mu \mathrm{L}$ ) was mixed with 0.1 $\mu \mathrm{L}$ of $E$. coli total cell lysate containing Nup2p-GST (generous gift from David Dilworth and John Aitchison ${ }^{23}$ ) and brought to a total volume of $500 \mu \mathrm{L}$ with TB-T, $1 \mathrm{mM} \mathrm{DTT}, 4 \mu \mathrm{g} / \mathrm{mL}$ pepstatin, $0.2 \mathrm{mg} / \mathrm{mL}$ PMSF. Controls were set up in the absence of either Kap95p-PrA or Nup2p-GST. The samples were incubated at $25{ }^{\circ} \mathrm{C}$ for $30 \mathrm{~min}$ after which $40 \mu \mathrm{L}$ of packed, pre- 

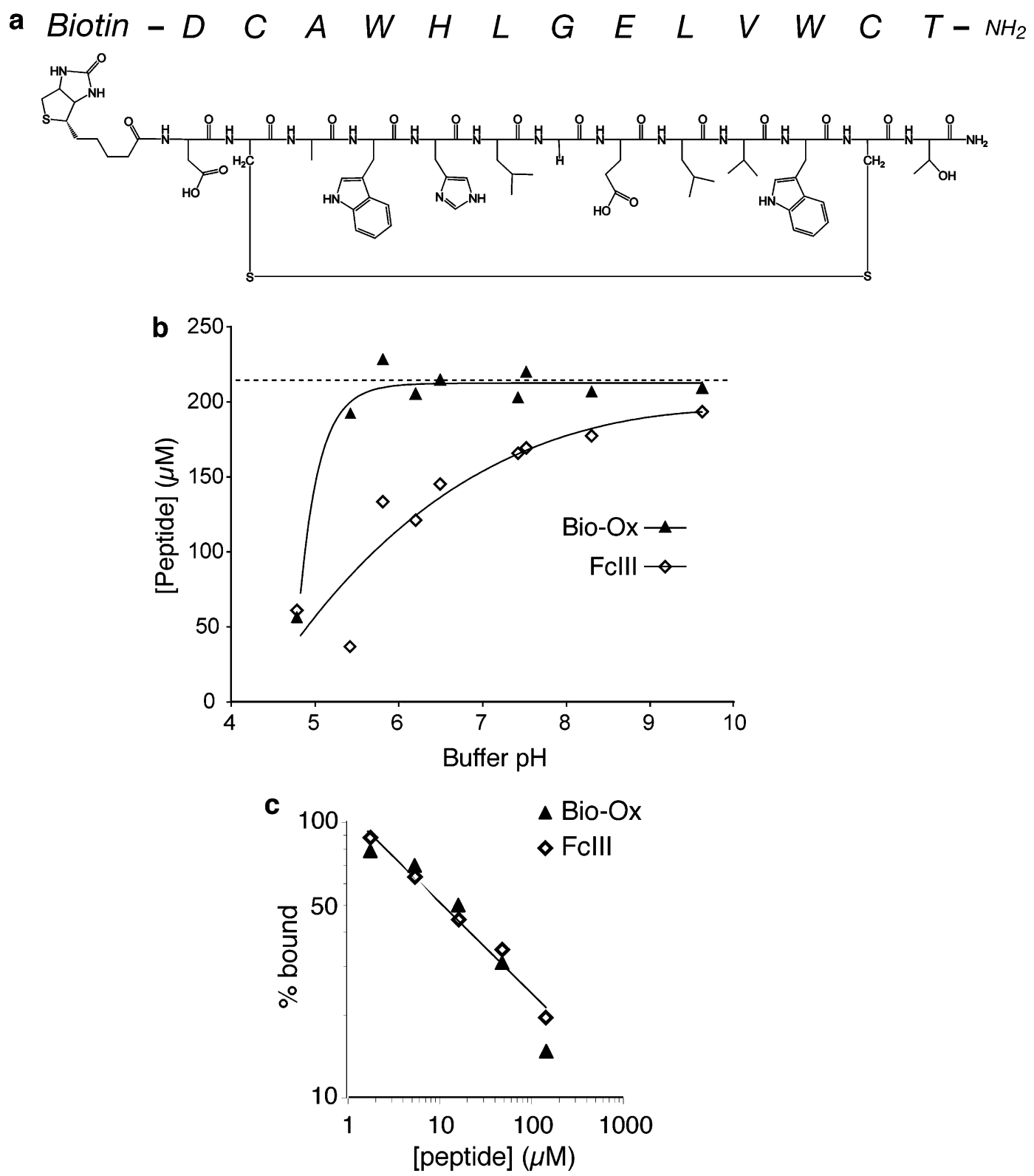

Figure 1. Addition of a Biotin moiety to the Fclll peptide does not alter the ability of the peptide to competitively displace bound PrA from IgG-Sepharose. (a) Primary sequence and chemical structure of the biotinylated Fclll peptide, Bio-Ox. (b) $220 \mu \mathrm{M}$ suspensions of peptides were prepared in buffers of different $\mathrm{pHs}$, and allowed to solubilize. The material remaining in the buffer after centrifugation is plotted for Bio-Ox (closed triangles, black trend line) and Fclll (open circles, gray trend line; dashed horizontal line represents the starting $220 \mu \mathrm{M}$ level. (c) Increasing amounts of Bio-Ox (closed triangles) and Fclll (open diamonds) were used to competitively displace recombinant PrA from lgG-Sepharose. The amounts of PrA left on the resin after elution were resolved by SDS-PAGE alongside known amounts of PrA standards. The data are displayed on logarithmic scale on both axes. Data are displayed as a \% recovery relative to the input PrA amount (i.e., PrA amount remaining bound in the absence of eluting peptide). Linear regression for both data sets was used to calculate the IC50.

equilibrated glutathione-Sepharose 4B resin (Amersham Biosciences) was added per sample and the incubation was continued at $4{ }^{\circ} \mathrm{C}$ for $1 \mathrm{~h}$. After nine washes with $1 \mathrm{~mL}$ of TBT, $1 \mathrm{mM}$ DTT, $4 \mu \mathrm{g} / \mathrm{mL}$ pepstatin, $0.2 \mathrm{mg} / \mathrm{mL}$ PMSF, at $25^{\circ} \mathrm{C}$, the resin was recovered on Bio-Spin columns as described above and bound material was eluted with $40 \mu \mathrm{L}$ of sample buffer. The samples were resolved on SDS-PAGE alongside an aliquot of input peptide-eluted Kap95p-PrA.

To demonstrate the recovery of in vitro reconstituted protein complexes from the resin, Kap95p-PrA from $0.3 \mathrm{~mL}$ of yeast cytosol was affinity-purified on $10 \mu \mathrm{L}$ of packed IgG-Sepharose and the washed resin was equilibrated in TB-T, 1 mM DTT, 4 $\mu \mathrm{g} / \mathrm{mL}$ pepstatin, $0.2 \mathrm{mg} / \mathrm{mL}$ PMSF. This pre-bound Kap95pPrA was mixed with $50 \mu \mathrm{L}$ of $E$. coli total cell lysate containing Nup2p-GST in a total volume of $1 \mathrm{~mL}$ of TB-T, $1 \mathrm{mM}$ DTT, 4 $\mu \mathrm{g} / \mathrm{mL}$ pepstatin, $0.2 \mathrm{mg} / \mathrm{mL}$ PMSF. A mock control experiment was set up in the absence of Nup2p-GST. The binding reaction was carried out for $1 \mathrm{~h}$ at $4{ }^{\circ} \mathrm{C}$ and the resin was washed 2 times with $1 \mathrm{~mL}$ of TB-T, 2 times with $1 \mathrm{~mL}$ of TB-T containing $100 \mu \mathrm{M}$ ATP and 3 times with peptide buffer (all washed were without DTT). Bound material was eluted with $30 \mu \mathrm{L}$ of 440 $\mu \mathrm{M}$ Bio-Ox in peptide buffer at $4{ }^{\circ} \mathrm{C}$ for $2.5 \mathrm{~h}$ at $4{ }^{\circ} \mathrm{C}$ followed by $1 \mathrm{~h}$ at $25^{\circ} \mathrm{C}$. Samples were resolved by SDS-PAGE. 


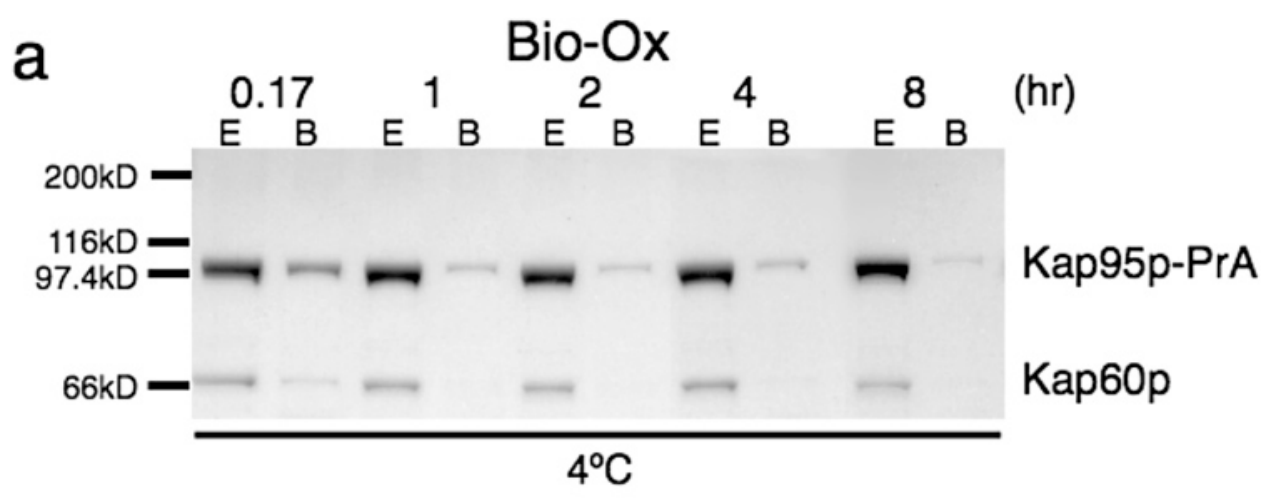

b

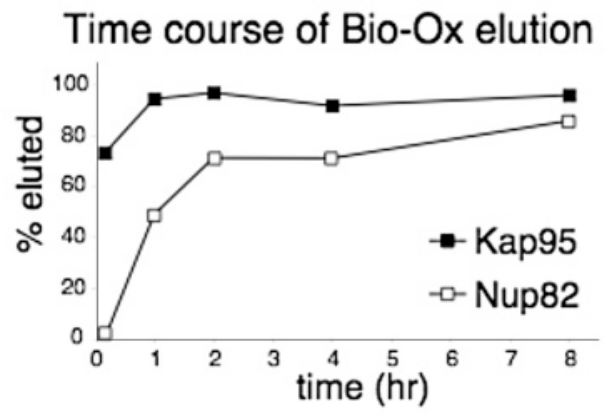

C

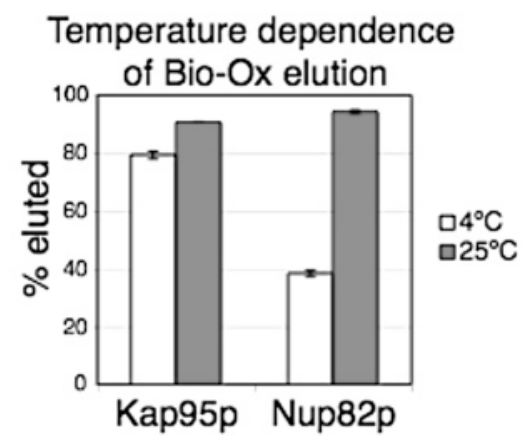

Figure 2. Bio-Ox can be used to efficiently compete bound PrA-tagged proteins and protein complexes from IgG-Sepharose in a temperature-dependent fashion. (a) Kap95p-PrA/Kap60p was affinity-purified on IgG-Sepharose from logarithmically growing yeast cells. $440 \mu \mathrm{M}$ Bio-Ox was used to competitively displace the bound tagged proteins from the lgG-Sepharose resin. The elution reaction was carried out for the times indicated. At the end of the incubation time eluted proteins $(E)$ and proteins remaining bound to the resin $(B)$ were resolved on SDS-PAGE. (b) Kap95p-PrA (closed squares) and Nup82p-PrA (open squares) were affinity-purified on IgG-Sepharose from logarithmically growing yeast cells and eluted as described above. The amounts of eluted versus resin-bound protein was quantified using the OpenLab software and the elution efficiency for each time point is presented as the percentage of eluted material over the total amount of bound plus eluted material (\% eluted). (c) $440 \mu \mathrm{M}$ Bio-Ox was used to elute Kap95p-PrA or Nup82p-PrA for $1 \mathrm{~h}$ at $4{ }^{\circ} \mathrm{C}$ or $25^{\circ} \mathrm{C}$ as indicated.

Quantitation and Image Analyses. Band intensities were quantified with the Openlab software (Improvision), and the data was plotted using Excel (Microsoft).

\section{Results and Discussion}

Design of the PrA Mimicking Peptide. The hinge region on the Fc fragment of immunoglobulin G (IgG) interacts with Staphylococcus aureus Protein A (PrA). This region was also found to be the preferred binding site for peptides selected by bacteriophage display from a random library. ${ }^{16}$ The specific Fc binding interactions of a selected 13 amino acid peptide (termed FcIII), were shown to closely mimic those of natural Fc binding partners. We reasoned that this peptide could be used to efficiently displace PrA tagged proteins from IgG- conjugated affinity resins. Initial trials with FcIII determined that, although it functioned as an eluant, it exhibited a strong tendency to aggregate and its solubility under physiological conditions was not sufficient for many practical purposes, leading to low yields and nonreproducible results. As the high peptide concentrations needed for elution are outside the conditions for which the FcIII peptide was designed, we synthesized several modified peptides based on FcIII, with the specific aim of increasing their solubility and decreasing their degree of aggregation under conditions that would be useful for the isolation of proteins and protein complexes. Among the different alternatives, the most efficient in the displacement of bound PrA-tagged Kap95p from IgG-Sepharose was a peptide in which the amino-terminus of the original FcIII peptide was 


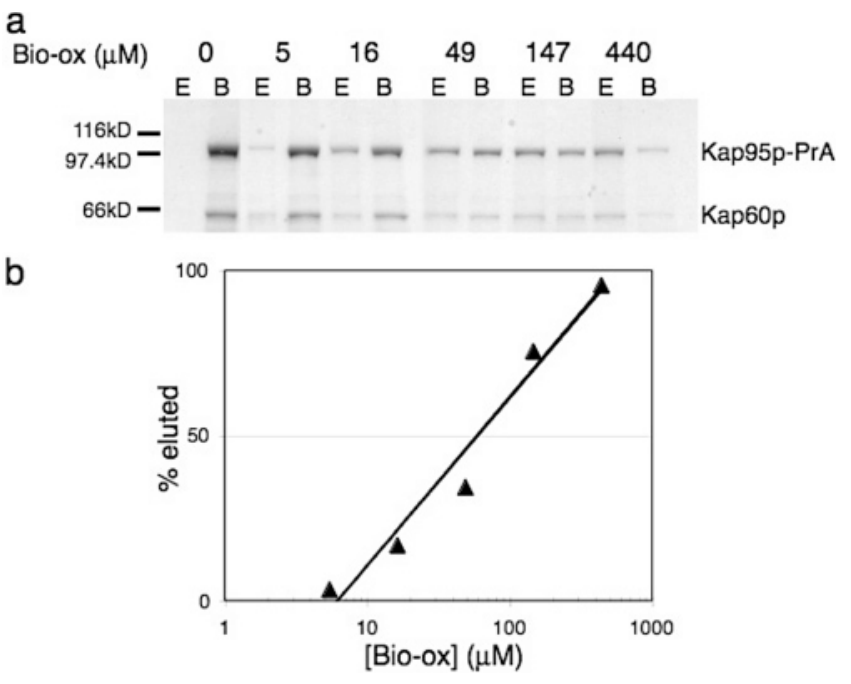

Figure 3. Elution of Kap95-PrA/Kap60p is dose dependent. (a) Kap95p-PrA was affinity-purified on IgG-Sepharose from logarithmically growing yeast cells and eluted using increasing concentrations of Bio-Ox peptide as indicated. (b) The elution efficiency measured as described in Figure 2 was plotted versus the peptide concentration in logarithmic scale as indicated.

modified by the addition of a Biotin moiety (data not shown). We termed this peptide Bio-Ox (Figure 1, panel a). The solubility of Bio-Ox was measured directly by amino acid analysis and was shown to be $\sim 3$-fold greater than the solubility of FcIII at $\mathrm{pH}$ 7.4. In addition, comparison of the solubility of both peptides over a range of pHs indicated that the Bio-Ox was considerably more soluble than FcIII at all but the most extreme pHs tested; importantly, Bio-Ox is very soluble across the full physiological range of pHs (Figure 1, panel b).

To determine whether the addition of the Biotin moiety could have altered the inhibiting ability of the peptide, we measured the inhibition constant for Bio-Ox and found it to be comparable with the reported $K_{\mathrm{i}}$ for FcIII $(\sim 11 \mathrm{nM}$; data not shown). We then measured the $\mathrm{IC}_{50}$ for competitive displacement for FcIII and Bio-Ox, under conditions in which both were soluble. For this test, commercially available recom-
Table 1. Elution Efficiency for PrA Tagged Nups

\begin{tabular}{lc}
\hline name of nup & \% yield \\
\hline Nup53p & 56 \\
Nup59p & 81 \\
Nup84p & 88 \\
Nup85p & 81 \\
Nic96p & 76 \\
Nsp1p & 99 \\
Nup1p & 99 \\
Nup120p & 69 \\
Nup157p & 82 \\
Nup159p & 53 \\
Nup170p & 80 \\
Nup192p & 76 \\
Gle2p & 90
\end{tabular}

binant PrA from S. aureus was first bound to IgG-Sepharose and then increasing concentrations of the peptide were used to displace the bound PrA from the immobilized IgG (Figure 1 , panel c). The apparent $\mathrm{IC}_{50}$ was found to be $10.4 \pm 3.2 \mu \mathrm{M}$ for FcIII and $9.8 \pm 2.6 \mu \mathrm{M}$ for Bio-Ox (mean value of four independent trials \pm standard deviation of the mean). Taken together, Bio-Ox appears to be as efficient as FcIII at binding to the $F_{\mathrm{c}}$ portion of antibodies and competing for this site with Protein A, but is far more soluble in physiologically compatible buffers, a key requirement for an efficient elution peptide (Figure 3).

Experimental Design of the Competitive Elution Procedure. The principle of the method is as follows; genomically PrAtagged proteins of interest are expressed in yeast and affinity isolated on IgG-conjugated Sepharose resin. Depending on the conditions used for lysis and extraction, the test protein can be recovered in native form either in isolation or in complexes with protein partners. After binding, the resin is recovered by centrifugation and washed extensively to remove unbound material. The bound material is competitively displaced from the IgG-Sepharose resin by incubation with $440 \mu \mathrm{M}$ Bio-Ox peptide in peptide buffer for $2 \mathrm{~h}$ at $4{ }^{\circ} \mathrm{C}$. Finally, the peptide is rapidly ( $<1 \mathrm{~min}$ ) removed from the eluted sample by fractionation over a size exclusion spin column. Given a typical protein of average abundance, $1-10 \mu \mathrm{g}$ of pure protein can be recovered from $1 \mathrm{~g}$ of cells using this method.

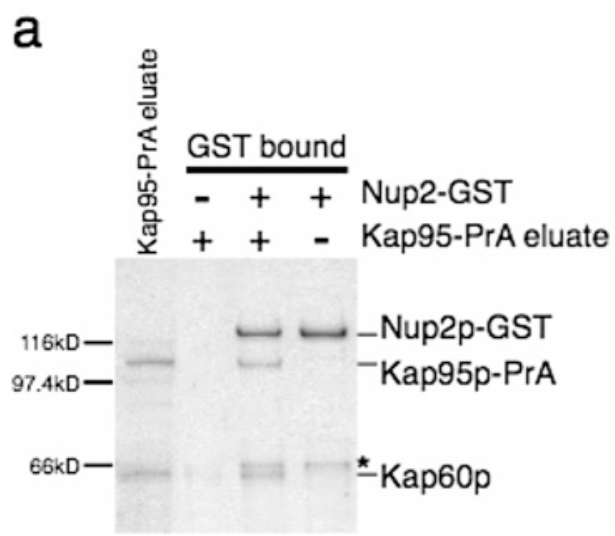

b

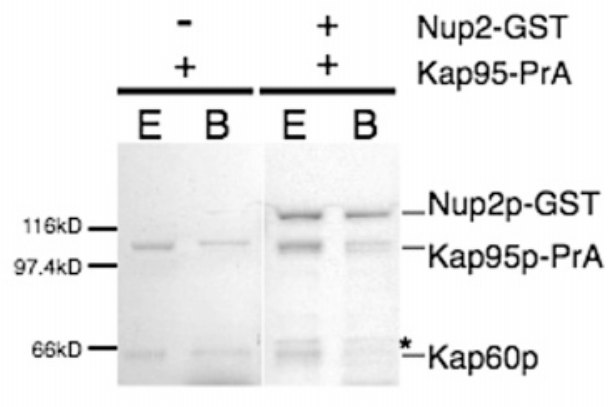

Figure 4. Eluted Kap95p-PrA/Kap60 complex retains its biological activity. (a) Kap95p-PrA was prepared by affinity purification followed by Bio-Ox peptide elution (Kap95-PrA eluate). Three binding reactions were then set up containing eluted Kap95p-PrA and Nup2p-GST bacterial lysate, Kap95p-PrA alone or Nup2p-GST alone. At the end of the incubation, Nup2p-GST was affinity-purified on glutathioneSepharose and the immobilized material was eluted from the resin with sample buffer and resolved on SDS-PAGE (GST bound). (b) Kap95p-PrA was immobilized on IgG-Sepharose and incubated with $(+)$ or without $(-)$ bacterial lysate containing Nup2p-GST. The resulting material was eluted using Bio-Ox. Eluate $(E)$ and resin bound $(B)$ material was resolved on SDS-PAGE. ${ }^{*}$, indicates a Nup2p breakdown product. 
To explore the characteristics of Bio-Ox elution under conditions that preserve native protein complexes, we chose to work with the yeast karyopherin Kap95p-PrA/Kap60p complex, ${ }^{24}$ and with the yeast nucleoporin Nup82p-PrA/Nsplp/ Nup159p complex. ${ }^{25,26}$ This choice was dictated by our interest in the structure and function of the yeast nuclear pore complex (NPC). ${ }^{17,27}$

Optimization of the Elution Conditions. An elution time course for Kap95p-PrA/Kap60p and Nup82p-PrA from IgGSepharose at $4{ }^{\circ} \mathrm{C}$ is shown in Figure 2, panels a and b. In both cases, the elution was virtually complete after $2 \mathrm{~h}$ at $4{ }^{\circ} \mathrm{C}$. The largest difference in elution efficiency between the two test proteins was found at the earlier time points. Thus, more than $50 \%$ of initially bound Kap95p-PrA was displaced by $10 \mathrm{~min}$, while it took $\sim 1$ h to obtain the same result with Nup82p-PrA. We also determined the temperature dependence of the elution process (Figure 2, panel c). Elutions of Kap95p-PrA and Nup82p-PrA with Bio-Ox, for $1 \mathrm{~h}$ were compared at $4{ }^{\circ} \mathrm{C}$ and $25{ }^{\circ} \mathrm{C}$ (Figure 2, panel c), showing that elution was improved at $25{ }^{\circ} \mathrm{C}$ over $4{ }^{\circ} \mathrm{C}$ for both test proteins. These various factors underscore the need to conduct appropriate test experiments to determine the optimal conditions for any given application. For example, elution for shorter periods and at $4{ }^{\circ} \mathrm{C}$ is preferable when the proteins under study are sensitive to denaturation, dissociation or proteolytic degradation.

We also tested the dependence of elution efficiency upon Bio-Ox concentration. For this test, Kap95p-PrA bound to IgGSepharose was competitively displaced using increasing amounts of Bio-Ox peptide for $4 \mathrm{~h}$ at $4{ }^{\circ} \mathrm{C}$. (Figure 3). Bio-Ox peptide displaced IgG-Sepharose bound PrA tagged Kap95p with an apparent $\mathrm{IC}_{50}$ of $60.8 \mu \mathrm{M}$. For practical purposes, the protocol we use in most cases takes advantage of the high solubility of Bio-Ox to obtain maximally efficient elutions, utilizing a concentration of $440 \mu \mathrm{M}$ of Bio-Ox peptide for $2 \mathrm{~h}$ at $4{ }^{\circ} \mathrm{C}$.

To test the general applicability of the method, we performed peptide elution experiments using a series of PrA tagged proteins that were available in our laboratories. ${ }^{17}$ The yield for these proteins was in all cases $>50 \%$ and in most cases was $>80 \%$ (average yield $78 \% \pm 14 \%$; Table 1 ).

Eluted Proteins Retain their Biological Activity. The translocation of macromolecules between the nucleus and cytosol of eukaryotic cells occurs through the NPC and is facilitated by soluble transport factors termed karyopherins (reviewed in ref 28). Nucleoporins that contain FG peptide repeats (FG Nups) function as binding sites for karyopherins within the NPC. One example of an FG Nup-karyopherin interaction is represented by the binding of the Kap95p/Kap60p complex to Nup2p, ${ }^{29}$ an interaction that requires both karyopherins to be natively folded. ${ }^{30,31}$ We took advantage of this interaction to demonstrate that the Bio-Ox eluted Kap95p-PrA/Kap60p complex retains its biological activity and is able to bind Nup2p in vitro (Figure 4, panel a). In this test, Kap95p-PrA was affinitypurified and eluted from IgG-Sepharose as described above. The eluate was incubated with whole cell lysate from $E$. coli expressing Nup2p-GST, ${ }^{23}$ and GST-tagged Nup2p was isolated over gluthatione-Sepharose resin. As a control, the same experiment was performed either in the absence of Nup2pGST containing bacterial lysate or in the absence of Kap95pPrA eluate. As shown, Nup2p-GST binds specifically and directly to the peptide-eluted Kap95p-PrA/Kap60p complex. This result is consistent with reported data and demonstrates that elution with Bio-Ox does not alter the native state and biological activity of Kap95p-PrA. Moreover, the apparent equimolar stoichiometry of the Nup2-GST/Kap95p-PrA/Kap60p complex indicates that essentially all of the peptide eluted karyopherins were in their native, active conformation. This result underscores the usefulness of this method for the preparation of native protein samples.

The method can also be used for in vitro reconstitution experiments of biologically relevant protein-protein interactions of interest. For this test, Kap95p-PrA was affinity isolated on IgG-Sepharose, Nup2p-GST was bound to the immobilized Kap95p-PrA and then the reconstituted complex was competitively displaced from the resin by Bio-Ox peptide elution (Figure 4 , panel b). This shows that the method can be used in vitro to study protein -protein interactions using purified components.

\section{Conclusion}

We have used the Bio-Ox technology extensively in our laboratories for a wide variety of applications including: (1) the semipreparative purification of $\sim 30$ PrA-tagged natively folded Nups for the determination of their sedimentation coefficient over a sucrose velocity gradient (S. Dokudovskaya, L. Veenhoff, personal communication); (2) the isolation of yeast cyclins and cyclin-Cdk associated proteins, ${ }^{32}$ (3) the semipreparative purification of enzymatically active Dpb4p-PrA chromatin remodeling/histone complexes; ${ }^{33}$ and (4) the study of the in vitro binding property of proteins of interest using blot and resin binding experiments. ${ }^{34}$ Thus, this method should be generally applicable to the native purification of most other proteins and protein complexes.

Acknowledgment. We are very grateful to David Dilworth and John Aitchison for the generous gift of bacterially expressed Nup2p-GST. We are deeply indebted to Rosemary Williams for her skilled technical assistance throughout the course of this study and to all members of the Rout and Chait laboratories and of the Proteomic Research Center, past and present, for their continual help and unwavering support. We are particularly grateful to Markus Kalkum, Bhaskar Chandrasekhar, Svetlana Dokudovskaya and Liesbeth Veenhoff. This work was supported by grants from the American Cancer Society (RSG-0404251) and the NIH (GM062427, RR00862, and CA89810).

\section{References}

(1) Uhlen, M.; Forsberg, G.; Moks, T.; Hartmanis, M.; Nilsson, B. Fusion proteins in biotechnology. Curr. Opin. Biotechnol. 1992, 3 (4), 363-369.

(2) Nygren, P. A.; Stahl, S.; Uhlen, M. Engineering proteins to facilitate bioprocessing. Trends Biotechnol. 1994, 12 (5), 184-188.

(3) Baneyx, F. Recombinant protein expression in Escherichia coli. Curr. Opin. Biotechnol. 1999, 10 (5), 411-421.

(4) LaVallie, E. R.; McCoy, J. M. Gene fusion expression systems in Escherichia coli. Curr. Opin. Biotechnol. 1995, 6 (5), 501-506.

(5) Nilsson, J.; Stahl, S.; Lundeberg, J.; Uhlen, M.; Nygren, P. A. Affinity fusion strategies for detection, purification, and immobilization of recombinant proteins. Protein Expr. Purif. 1997 11 (1), 1-16.

(6) Einhauer, A.; Jungbauer, A. The FLAG peptide, a versatile fusion tag for the purification of recombinant proteins. J. Biochem. Biophys. Methods 2001, 49 (1-3), 455-465.

(7) Aitchison, J. D.; Blobel, G.; Rout, M. P. Nup120p: a yeast nucleoporin required for NPC distribution and mRNA transport. J. Cell Biol. 1995, 131 (6 Pt 2), 1659-1675.

(8) Grandi, P.; Doye, V.; Hurt, E. C. Purification of NSP1 reveals complex formation with 'GLFG' nucleoporins and a novel nuclear pore protein NIC96. EMBO J. 1993, 12 (8), 3061-3071.

(9) Stirling, D. A.; Petrie, A.; Pulford, D. J.; Paterson, D. T.; Stark, M. J. Protein A-calmodulin fusions: a novel approach for investigating calmodulin function in yeast. Mol. Microbiol. 1992, 6 (6), 703713 . 
(10) Karlsson, R.; Jendeberg, L.; Nilsson, B.; Nilsson, J.; Nygren, P. A. Direct and competitive kinetic analysis of the interaction between human IgG1 and a one domain analogue of protein A. J. Immunol. Methods 1995, 183 (1), 43-49.

(11) He, M.; Jin, L.; Austen, B. Specificity of factor Xa in the cleavage of fusion proteins. J. Protein Chem. 1993, 12 (1), 1-5.

(12) Wagner, C. R.; Bergstrom, C. P.; Koning, K. R.; Hanna, P. E. Arylamine $\mathrm{N}$-acetyltransferases. Expression in Escherichia coli, purification, and substrate specificities of recombinant hamster monomorphic and polymorphic isozymes. Drug Metab. Dispos. 1996, 24 (2), 245-253.

(13) Stevens, R. C. Design of high-throughput methods of protein production for structural biology. Struct. Fold Des. 2000, 8 (9), R177-185.

(14) Forsberg, G.; Brobjer, M.; Holmgren, E.; Bergdahl, K.; Persson, P.; Gautvik, K. M.; Hartmanis, M. Thrombin and H64A subtilisin cleavage of fusion proteins for preparation of human recombinant parathyroid hormone. J. Protein Chem. 1991, 10 (5), 517526.

(15) Puig, O.; Caspary, F.; Rigaut, G.; Rutz, B.; Bouveret, E.; BragadoNilsson, E.; Wilm, M.; Seraphin, B. The tandem affinity purification (TAP) method: a general procedure of protein complex purification. Methods 2001, 24 (3), 218-229.

(16) DeLano, W. L.; Ultsch, M. H.; de Vos, A. M.; Wells, J. A. Convergent solutions to binding at a protein-protein interface. Science 2000, 287 (5456), 1279-1283.

(17) Rout, M. P.; Aitchison, J. D.; Suprapto, A.; Hjertaas, K.; Zhao, Y.; Chait, B. T. The yeast nuclear pore complex: composition, architecture, and transport mechanism. J. Cell Biol. 2000, 148 (4), $635-651$.

(18) Aitchison, J. D.; Blobel, G.; Rout, M. P. Kap104p: a karyopherin involved in the nuclear transport of messenger RNA binding proteins. Science 1996, 274 (5287), 624-627.

(19) Rout, M. P.; Blobel, G.; Aitchison, J. D. A distinct nuclear import pathway used by ribosomal proteins. Cell 1997, 89 (5), 715-725.

(20) Schultz, M. C.; Hockman, D. J.; Harkness, T. A.; Garinther, W. I. Altheim, B. A. Chromatin assembly in a yeast whole-cell extract. Proc. Natl. Acad. Sci. U.S.A. 1997, 94 (17), 9034-9039.

(21) Strambio-de-Castillia, C.; Blobel, G.; Rout, M. P. Isolation and characterization of nuclear envelopes from the yeast Saccharomyces. J. Cell Biol. 1995, 131 (1), 19-31.

(22) Kipper, J.; Strambio-de-Castillia, C.; Suprapto, A.; Rout, M. P. Isolation of nuclear envelope from Saccharomyces cerevisiae. Methods Enzymol. 2002, 351, 394-408.
(23) Dilworth, D. J.; Suprapto, A.; Padovan, J. C.; Chait, B. T.; Wozniak, R. W.; Rout, M. P.; Aitchison, J. D. Nup2p dynamically associates with the distal regions of the yeast nuclear pore complex. J. Cell Biol. 2001, 153 (7), 1465-1478.

(24) Enenkel, C.; Blobel, G.; Rexach, M. Identification of a yeast karyopherin heterodimer that targets import substrate to mammalian nuclear pore complexes. J. Biol. Chem. 1995, 270 (28), 16499-16502.

(25) Grandi, P.; Emig, S.; Weise, C.; Hucho, F.; Pohl, T.; Hurt, E. C. A novel nuclear pore protein Nup82p which specifically binds to a fraction of Nsplp. J. Cell Biol. 1995, 130 (6), 1263-1273.

(26) Hurwitz, M. E.; Blobel, G. NUP82 is an essential yeast nucleoporin required for poly(A)+ RNA export. J. Cell Biol. 1995, 130 (6), 1275-1281.

(27) Rout, M. P.; Blobel, G. Isolation of the yeast nuclear pore complex. J. Cell Biol. 1993, 123 (4), 771-783.

(28) Mosammaparast, N.; Pemberton, L. F. Karyopherins: from nuclear-transport mediators to nuclear-function regulators. Trends Cell. Biol. 2004, 14 (10), 547-556.

(29) Denning, D. P.; Uversky, V.; Patel, S. S.; Fink, A. L.; Rexach, M. The Saccharomyces cerevisiae nucleoporin Nup2p is a natively unfolded protein. J. Biol. Chem. 2002, 277 (36), 33447-33455.

(30) Denning, D.; Mykytka, B.; Allen, N. P.; Huang, L.; Al, B.; Rexach, M. The nucleoporin Nup60p functions as a Gsp1p-GTP-sensitive tether for Nup2p at the nuclear pore complex. J. Cell Biol. 2001, 154 (5), 937-950.

(31) Loeb, J. D.; Davis, L. I.; Fink, G. R. NUP2, a novel yeast nucleoporin, has functional overlap with other proteins of the nuclear pore complex. Mol. Biol. Cell 1993, 4 (2), 209-222.

(32) Archambault, V.; Chang, E. J.; Drapkin, B. J.; Cross, F. R.; Chait, B. T.; Rout, M. P. Targeted proteomic study of the cyclin-Cdk module. Mol. Cell. 2004, 14 (6), 699-711.

(33) Tackett, A. J.; Dilworth, D. J.; Davey, M. J.; O’Donnell, M.; Aitchison, J. D.; Rout, M. P.; Chait, B. T. Proteomic and genomic characterization of chromatin complexes at a boundary. J. Cell. Biol. 2005, 169 (1), 35-47.

(34) Niepel, M.; Strambio-de-Castillia, C.; Fasolo, J.; Chait, B. T.; Rout, M. P. The nuclear pore complex-associated protein, Mlp2p, binds to the yeast spindle pole body and promotes its efficient assembly. J. Cell. Biol. 2005, 170 (2), 225-35.

PR0501517 